\title{
WHAT DO YOU KNOW ABOUT SEXUALLY TRANSMITTED INFECTIONS? SURVEY CONCERNING KNOWLEDGE AND RISKY BEHAVIORS AMONG STUDENTS OF BIALYSTOK UNIVERSITIES
}

\author{
CO WIESZ O INFEKCJACH PRZENOSZONYCH DROGĄ PŁCIOWĄ? BADANIE \\ ANKIETOWE DOTYCZACE WIEDZY I RYZYKOWNYCH ZACHOWAŃ WŚRÓD \\ STUDENTÓW BIAŁOSTOCKICH UCZELNI WYŻSZYCH
}
${ }^{1}$ Scientific Society at the Department of Dermatology and Venereology Medical University of Białystok, Poland
${ }^{2}$ Medical University of Białystok Department of Dermatology and Venereology
${ }^{1}$ Studenckie Koło Naukowe przy Klinice Dermatologii i Wenerologii Uniwersytetu Medycznego w Białymstoku, Polska
${ }^{2}$ Uniwersytet Medyczny w Białymstoku, Klinika Dermatologii i Wenerologii

\begin{abstract}
INTRODUCTION. Sexually-transmitted infections (STIs) are serious public health problem, being acquired by more than 1 million people every day worldwide.

OBJECTIVE. Assess the knowledge, attitudes, risky behaviors and preventive practices related to STIs among medical and non-medical faculties students from Bialystok.

MATERIALS AND METHODS. In 2018 an original anonymous survey was carried among 168 subjects from medical and 142 from non-medical universities. They filled 37 questions: general and specific regarding STI. Statistical analysis was performed using Chi-Square test, statistically significant difference was at $\mathrm{p}=0.05$.

RESULTS. In the group $80,6 \%$ were females and $19,4 \%$ males, with a mean age of 21,9 years. Over $73 \%$ were sexually active and almost half of them admitted risky sexual behavior in the past. Almost $16 \%$ have ever done an examination for STIs. HIV remains the best known STIs, while hepatitis B was known mainly among medical students. Three fourth students knew that STIs could be asymptomatic. Over half of the students knew that vaccinations against STIs were available and $88,6 \%$ of them heard about the HPV vaccine. There was statistically significant difference between the groups regarding the knowledge of diseases transferred sexually, causative agents, history of STI examination, vaccines against STIs.

CONCLUSIONS. Almost all participants identified HIV as STIs. Unfortunately, knowledge about other STIs is still at lower level. Both groups have indicated the Internet as a source of knowledge about STIs and the need to acquire additional education about these diseases. To conclude, non-medical students have less awareness about STIs.
\end{abstract}

Key words: Sexually Transmitted Infections, knowledge, awareness, students

\section{STRESZCZENIE}

WSTĘP. Infekcje przenoszone drogą płciową (sexually transmitted infections - STIs) są poważnym problemem zdrowia publicznego, wykrywanym u ponad 1 miliona osób każdego dnia na całym świecie.

CEL PRACY. Analiza wiedzy, ryzykownych zachowań oraz działań prewencyjnych dotyczących STIs wśród studentów kierunków medycznych i niemedycznych białostockich uczelni.

MATERIAŁ I METODY. W 2018 roku przeprowadzono anonimową ankietę złożoną z 37 pytań wśród 168 studentów UMB i 142 studentów uczelni niemedycznych. Analizę statystyczną przeprowadzono w oparciu o test Chi-kwadrat, zakładając poziom istotności równy 0,05 .

(C) National Institute of Public Health - National Institute of Hygiene / Narodowy Instytut Zdrowia Publicznego - Państwowy Zakład Higieny 
WYNIKI. Kobiety stanowiły 80,6\% wszystkich respondentów, mężczyźni 19,4\%, średni wiek wynosił 21,9 roku. Ponad $73 \%$ ogółu osób była aktywna seksualnie, blisko połowa z nich deklarowała ryzykowne zachowania seksualne w przeszłości. Blisko $16 \%$ było badanych w kierunku STIs. Najbardziej rozpoznawaną przez respondentów STIs była infekcja HIV, podczas gdy zapalenie wątroby typu B było rozpoznawane tyko przez studentów kierunków medycznych. Blisko 3/4 studentów wiedziało, że STIs mogą przebiegać bezobjawowo. Ponad połowa studentów miała świadomość istnienia jakichkolwiek szczepień przeciwko STIs, 88,6\% z nich wskazywało szczepienie przeciwko HPV. Między grupami istniała różnica istotna statystycznie w zakresie wiedzy o chorobach przenoszonych drogą płciową i możliwych miejscach badania w ich kierunku, czynnikach etiologicznych oraz historii badania w kierunku STIs.

WNIOSKI. Niemal wszyscy respondenci potrafili wskazać infekcję HIV jako STIs. Niestety wiedza o innych STIs jest dużo mniejsza. Obie grupy wskazały potrzebę edukacji w zakresie STIs, a jako główne źródło swojej wiedzy podały internet. Podsumowując, studenci uczelni niemedycznych są mniej świadomi STIs.

Słowa kluczowe: infekcje przenoszone droga ptciowa, wiedza, świadomość, studenci

\section{INTRODUCTION}

Sexually Transmitted Infections (STIs) constitute a significant health problem worldwide, and their frequency has been increasing in recent years. STIs include, among others, chlamydiosis, gonorrhea, syphilis, hepatitis B, HIV infection, trichomoniasis, HPV infection, genital herpes and many more. They are caused by a variety of etiological factors: infection occurs not only through sexual contact, but also through blood, transplacental transmission and during childbirth (1). In Poland, the age of the first sexual intercourse is decreasing; in 2014, it was 14 years (2). In adolescence, the number of risky sexual behaviors may increase due to the neglect of risk and non-reflective imitation of peers. Recently, changes to sexual morality have been occurring as well: leaving traditional, religious behavior patterns, liberalization, weakening of parental control. Sexually active 18 -year-olds use as the following contraceptive methods: $56 \%$ condoms, $16 \%$ birth control pills, $13 \%$ natural methods and $22 \%$ intermittent intercourse. The increased incidence of STIs among adolescents is a consequence of an early sexual initiation, frequent change of partners and irregular condom use, as well as unsatisfactory level of knowledge about sexuality, intimate hygiene, preventive healthcare and the possibility of infection, also with HIV (3).

According to the report of the World Health Organization (WHO) from 2018, there are 1 million cases of STIs every day worldwide (1). Due to the size of the problem, in 2016, a document titled "Global health sector strategy on sexually transmitted infections 2016-2021" was published, presenting plans and strategies for reducing the incidence and increasing awareness of STIs among the general population. WHO recommends the widespread use of screening test for STIs. It is especially necessary in the following groups: men who have sex with men (MSM), people who have sexual contacts under the

\section{WSTĘP}

Zakażenia przenoszone drogą płciową (Sexually Transmitted Infections, STIs) stanowią istotny problem zdrowotny na świecie, a ich częstość w ostatnich latach wzrasta. Do STIs należą m.in. chlamydioza, rzeżączka, kiła, wirusowe zapalenie wątroby typu B (WZW B), infekcja HIV, rzęsistkowica, infekcja HPV, opryszczka narządów płciowych i wiele innych. Są one wywoływane przez różnorodne czynniki etiologiczne, do zakażenia dochodzi nie tylko poprzez kontakty seksualne, ale również przez krew, przezłożyskowo i podczas porodu (1). W Polsce dochodzi do obniżenia wieku odbycia pierwszego stosunku seksualnego, w 2014 roku wynosił on 14 lat (2). W okresie dojrzewania może zwiększać się liczba podejmowanych ryzykownych zachowań seksualnych ze względu na lekceważenie ryzyka, bezrefleksyjne naśladowanie rówieśników. Obecnie zaszły również zmiany w zakresie obyczajowości seksualnej: odejście od tradycyjnych, opartych na normach religijnych wzorów postępowania, liberalizacja, osłabienie kontroli rodziców. Aktywni seksualnie osiemnastolatkowie jako metody antykoncepcji stosują: 56\% prezerwatywy, 16\% pigułki antykoncepcyjne, 13\% metody naturalne oraz $22 \%$ stosunek przerywany. Zwiększona liczba zachorowań na STIs wśród młodzieży jest konsekwencją zbyt wczesnej inicjacji seksualnej, częstej zmiany partnerów i nieregularności w stosowaniu prezerwatyw, a także niezadowalającego poziomu wiedzy na temat seksualności, higieny intymnej, profilaktyki zdrowotnej i możliwości zakażenia, także wirusem HIV (3).

Według raportu Światowej Organizacji Zdrowia (World Health Organization - WHO) z 2018 roku dziennie na całym świecie dochodzi do 1 miliona zachorowań na STIs (1). Z racji powagi problemu, w 2016 roku wydano dokument pt.: „Global health sector strategy on sexually transmitted infections 2016-2021", który przedstawia plany oraz strategie dotyczące zmniejszenia zachorowań oraz zwiększenia świadomości populacji dotyczące infekcji przenoszonych drogą płciową. 
influence of psychoactive substances and in cases of an increased number of sexual partners. The purpose of WHO's activities is to reduce the number of cases by $90 \%$ compared to 2016 (4).

In Poland, control over infectious diseases is performed by the Department of Epidemiology of the National Institute of Public Health, which prepares a list of registered infectious diseases every year. The registry includes the following STIs: syphilis, gonorrhea, chlamydiosis, hepatitis B and HIV infection. In Poland, an increasing incidence of STIs is observed, but it should be emphasized that the recognition and reporting of these infections is largely underestimated. There is a burning need to educate and increase public awareness of sexually transmitted infections.

\section{OBJECTIVE}

Analysis and comparison of knowledge, risky behaviors and preventive practices related to sexually transmitted diseases among students of Bialystok universities.

\section{MATERIALS AND METHODS}

The study was conducted in 2018 using an original, anonymous questionnaire containing 37 general and specific questions about STIs. It was published on the Internet using Google Forms and made available on Facebook, in groups (Studenci UMB, Studenci Białystok, Studenci i Absolwenci Politechniki Białostockiej, Koło Prawa Medycznego i Farmaceutycznego „Pro Humanae Vitae” UwB, Prawo UwB 2018) gathering students of Bialystok universities from medical (med.) and non-medical (non-med.) faculties. The link to the questionnaire was publicly available and was completed by interested people on their own initiative. Out of 11,499 students who are members of student groups, 310 completed the form.

$168(54.2 \%)$ students of medical faculties (Medical University of Bialystok, UMB) and 142 (45.8\%) students of non-medical universities (University of Bialystok, Bialystok University of Technology) participated in the study. The obtained data was analyzed using GraphPad Prism5. Statistically significant differences between the groups were assessed using the $\mathrm{Chi}$-square test $\left(\mathrm{Chi}^{\wedge} 2\right)$, assuming the significance level equal to 0.05 .
WHO zaleca powszechne stosowanie badań przesiewowych w kierunku STIs. Jest to szczególnie konieczne w grupach: mężczyzn utrzymujących kontakty seksualne z mężczyznami (MSM, men who have sex with men), osób utrzymujących kontakty seksualne pod wpływem substancji psychoaktywnych oraz w przypadku zwiększonej liczby partnerów seksualnych. Celem działań WHO jest ograniczenie liczby zachorowań o 90\% w stosunku do roku 2016 (4).

W Polsce kontrolę nad chorobami zakaźnymi sprawuje Zakład Epidemiologii Narodowego Instytutu Zdrowia Publicznego, który co roku przygotowuje wykaz rejestrowanych chorób zakaźnych. Do STIs, które znajdują się w tym rejestrze należą kiła, rzeżączka, chlamydioza, WZW B oraz infekcja HIV. Obserwuje się trend wzrostowy zachorowań na STIs również w Polsce, należy jednak podkreślić, że rozpoznawalność oraz zgłaszalność tych infekcji jest w dużym stopniu niedoszacowana. Tym bardziej należy zwrócić uwagę na potrzebę edukacji i zwiększenia świadomości społeczeństwa na temat zakażeń przenoszonych drogą płciową.

\section{CEL PRACY}

Analiza i porównanie wiedzy, ryzykownych zachowań oraz działań prewencyjnych dotyczących chorób przenoszonych drogą płciową wśród studentów białostockich uczelni wyższych.

\section{MATERIAŁ I METODY}

Badanie przeprowadzono w 2018 roku przy użyciu autorskiej, anonimowej ankiety zawierającej 37 pytań ogólnych i szczegółowych dotyczących STIs. Została ona opublikowana w Internecie przy użyciu Formularze Google i udostępniona na portalu Facebook, w grupach (Studenci UMB, Studenci Białystok, Studenci i Absolwenci Politechniki Białostockiej, Koło Prawa Medycznego i Farmaceutycznego „Pro Humanae Vitae” UwB, Prawo UwB 2018), skupiających studentów białostockich uczelni wyższych, kierunków medycznych (med.) i niemedycznych (niemed.). Link do ankiety był ogólnodostępny i wypełniały ją osoby zainteresowane, z własnej inicjatywy. Spośród 11499 studentów będących członkami grup studenckich 310 osób wypełniło formularz.

W badaniu wzięło udział 168 (54,2\%) studentów kierunków medycznych (Uniwersytetu Medycznego w Białymstoku, UMB), oraz 142 (45,8\%) - uczelni niemedycznych (Uniwersytet w Białymstoku, Politechnika Białostocka). Uzyskane dane analizowano przy użyciu GraphPad Prism5. Istotne statystycznie różnice między grupami oceniano przy użyciu testu Chi-kwadrat (Chi^2) zakładając poziom istotności równy 0,05 . 


\section{RESULTS}

Among the respondents, $80.6 \%$ (250) were women and $19.4 \%$ (60) men. The age of the respondents ranged from 18 to 35 years, on average 22 years (Tab. I.). Sexual activity was declared by $73.2 \%$ (227, 95\% confidence interval - CI: 68-78) of people, and there was no statistical difference between these two groups $(\mathrm{p}=0.30)$.Of those who were sexually active, $47.1 \%$ (107, 95\% CI: 41 - 53) admitted to risky sexual behavior in the past (e.g. intercourse after alcohol, drugs, unprotected); no statistically significant difference was found between medical and nonmedical students $(\mathrm{p}=0.72)$. Only $24.3 \%(26,95 \%$ CI: 16 - 32) of people declaring risky sexual behavior had ever been tested for STIs, but this difference was not statistically significant. In case of risky sexual behavior, $50.6 \%(157,95 \%$ CI: 45 - 56) respondents declared they would go to their doctor first -, 31.6\% (98, 95\% CI: 26 - 37) would look for information on the Internet and $7.7 \%$ (24, 95\% CI: 5 - 11) would wait for disease symptoms. There were no statistical differences in the above-mentioned responses in both groups of students. Among the respondents, 13.5\% (42, 95\% CI: 10 - 17) admitted having had more than one sexual partner in the last 12 months. Unfortunately, only $23.8 \%$ (10 people, $95 \%$ CI: 10 37) of the above-mentioned respondents performed an STI test in the last year, but this difference was not statistically significant (Tab. II). Among the contraceptive methods used, the respondents mentioned: condoms - 187 picks $(60.3 \%, 95 \%$ CI: 55 - 66), contraceptive pills - 77 picks $(24.8 \%, 95 \% \mathrm{CI}$ : 20 - 30), natural methods - 37 picks $(11.9 \%, 95 \%$ CI: 08 - 15), IUD -7 picks (2.2\%, 95\% CI: 0.6 - 3.9), intermittent intercourse -6 picks $(1.9 \%, 95 \%$ CI: 0.4 - 3,5$)$, contraceptive patch -3 picks $(0.9 \%, 95 \%$ CI: $-0.1-2.1)$, vaginal ring -2 picks $(0.6 \%, 95 \%$ CI: -0.3 - 1.5) (Tab. III.) A statistically significant difference in the use of contraceptive methods was demonstrated: medical students chose condoms significantly more often $(p=0.024)$, and non-medical students chose intermittent intercourse $(\mathrm{p}=0.007)$.

\section{WYNIKI}

Wśród badanych osób kobiety stanowiły 80,6\% (250), mężczyźni 19,4\% (60). Wiek respondentów wynosił od 18 do 35 lat, średnio 22 lata (Tab. I.) Aktywność seksualną deklarowało $73,2 \%$ (227, 95\% przedział ufności (confidence interval) - CI: 68 - 78) osób, nie wykazano różnicy statystycznej między obiema grupami $(\mathrm{p}=0,30)$. Spośród osób aktywnych seksualnie 47,1\% (107, 95\% CI: 41 - 53) przyznało się do ryzykownych zachowań seksualnych w przeszłości (np. stosunek po alkoholu, narkotykach, bez zabezpieczenia), nie odnotowano istotnej statystycznie różnicy między studentami med. i niemed. $(\mathrm{p}=0,72)$. Tylko $24,3 \%(26,95 \%$ CI: 16 - 32) osób deklarujących ryzykowne zachowania seksualne miało wykonane kiedykolwiek badanie w kierunku STIs, jednak ta różnica nie była istotna statystycznie. W przypadku wystąpienia ryzykownego zachowania seksualnego respondenci w pierwszej kolejności udaliby się do lekarza - 50,6\% (157, 95\% CI: 45 -56), szukaliby informacji w internecie 31,6\% (98, 95\% CI: 26 - 37) oraz czekaliby na objawy choroby $7,7 \%$ ( 24 , 95\% CI: 5 - 11). Nie wykazano różnic statystycznych w wymienionych odpowiedziach w obu grupach studentów. Spośród ankietowanych, 13,5\% osób (42, 95\% CI: 10 - 17) przyznało, że w ciągu ostatnich 12 miesięcy miało więcej niż jednego partnera seksualnego. Niestety, tylko 23,8\% (10 osób, 95\% CI: 10 - 37) spośród wyżej wymienionych respondentów wykonało badanie w kierunku STIs w ostatnim roku, jednak ta różnica nie była istotna statystycznie (Tab. II.). Wśród stosowanych metod antykoncepcji ankietowani podali: prezerwatywy 187 (60,3\%, 95\% CI: 55 - 66), tabletki antykoncepcyjne 77 (24,8\%, 95\% CI: 20 - 30), metody naturalne 37 (11,9\%, 95\% CI: 08 - 15), wkładka domaciczna 7 (2,2\%, $95 \%$ CI: $0,6-3,9)$, stosunek przerywany $6(1,9 \%, 95 \%$ CI: $0,4-3,5)$, plaster antykoncepcyjny $3(0,9 \%, 95 \%$ CI: -0,1 - 2,1), krążek dopochwowy $2(0,6 \%, 95 \% \mathrm{CI}$ : $-0,3-1,5)$ (Tab. III.) Wykazano istotnie statystyczną różnicę w stosowaniu metod antykoncepcji: studenci kierunków medycznych znamiennie częściej wybierali prezerwatywy $(\mathrm{p}=0,024)$, a studenci niemedyczni stosunek przerywany $(p=0,007)$. Studenci Uniwersytetu

Table I. Participants characteristics.

Tabela I. Charakterystyka badanej grupy.

\begin{tabular}{|c|c|c|c|}
\hline & UMB & Uczelnie niemed. & Ogólem \\
\hline $\mathbf{N}$ & $168(54,2 \%)$ & $142(45,8 \%)$ & $310(100 \%)$ \\
\hline Kobiety (K) & $132(78,6 \%)$ & $118(83,1 \%)$ & $250(80,6 \%)$ \\
\hline Mężczyźni (M) & $36(21,4 \%)$ & $24(16,9 \%)$ & $60(19,3 \%)$ \\
\hline Średni wiek & 22,02 & 21,7 & 21,9 \\
\hline Min. wiek & 18 & 18 & 35 \\
\hline Max. wiek & 34 & 35 & $227(73,2 \%)$ \\
\hline Aktywność seksualna & $127(41 \%)$ & $100(32,2 \%)$ & 18 \\
\hline
\end{tabular}


Table II. Answers concerning basic sexual behaviours.

Tabela II. Odpowiedzi dotyczące podstawowych zachowań seksualnych.

\begin{tabular}{|c|c|c|c|c|}
\hline & \multirow{2}{*}{ Ogółem, 95\% CI } & \multicolumn{2}{|c|}{ Studenci } & \multirow{2}{*}{$\mathrm{p}$} \\
\hline & & medyczni & niemedyczni & \\
\hline Aktywność seksualna & $227(73,2 \%), 68-78$ & $41 \%$ & $32,2 \%$ & ns \\
\hline $\begin{array}{l}\text { Ryzykowne zachowania seksualne (wśród } \\
\text { osób aktywnych seksualnie) }\end{array}$ & $107(47,1 \%), 41-53$ & $19 \%$ & $15,2 \%$ & ns \\
\hline $\begin{array}{l}\text { Badanie w kierunku STIs kiedykolwiek } \\
\text { (wśród osób podejmujących ryzykowne } \\
\text { zachowania seksualne) }\end{array}$ & $26(24,3 \%), 16-32$ & $15,9 \%$ & $8,4 \%$ & ns \\
\hline \multicolumn{5}{|c|}{ Postępowanie w przypadku ryzykownego zachowania seksualnego } \\
\hline - Wizyta u lekarza & $157(50,6 \%), 45-56$ & $29,3 \%$ & $21,3 \%$ & ns \\
\hline - Szukanie informacji w Internecie & $98(31,6 \%), 26-37$ & $16,5 \%$ & $15,2 \%$ & ns \\
\hline - Oczekiwanie na objawy choroby & $24(7,7 \%), 5-11$ & $3,5 \%$ & $4,2 \%$ & $\mathrm{~ns}$ \\
\hline $\begin{array}{l}\text { Czy w ciągu ostatnich } 12 \text { miesięcy miałeś } \\
\text { więcej niż } 1 \text { partnera seksualnego? Tak /Nie }\end{array}$ & $\begin{array}{c}42(13,5 \%) / 268(86,5 \%) \\
10-17\end{array}$ & $7,7 \% / 92,3 \%$ & $5,8 \% / 94,2 \%$ & $\mathrm{~ns}$ \\
\hline $\begin{array}{l}\text { Badanie w kierunku STIs w ciągu ostatnich } \\
12 \text { miesięcy (wśród osób, które miały więcej } \\
\text { niż } 1 \text { partnera seksualnego) }\end{array}$ & $10(23,8 \%), 10-37$ & $16,7 \%$ & $7,1 \%$ & $\mathrm{~ns}$ \\
\hline
\end{tabular}

ns - not significant, nieistotne statystycznie

Table III. Contraception methods used by medical and non-medical students.

Tabela III. Metody antykoncepcji stosowane przez studentów medycznych i niemedycznych.

\begin{tabular}{|l|c|c|c|c|}
\hline \multirow{2}{*}{ Rodzaj antykoncepcji } & \multirow{2}{*}{ Ogółem, 95\% CI } & \multicolumn{2}{c|}{ Studenci } \\
\cline { 3 - 5 } & & Medyczni (\%) & $\begin{array}{c}\text { Niemedyczni } \\
(\%)\end{array}$ & $\mathrm{p}$ \\
\hline Prezerwatywy & $187(60,3 \%), 55-66$ & $111(35,8 \%)$ & $76(24,5 \%)$ & $\mathbf{0 , 0 2 4 4}$ \\
\hline Tabletki antykoncepcyjne & $77(24,8 \%), 20-30$ & $44(14,2 \%)$ & $33(10,6 \%)$ & $\mathrm{ns}$ \\
\hline Naturalne metody antykoncepcji & $37(11,9 \%), 8-15$ & $20(6,5 \%)$ & $17(5,5 \%)$ & $\mathrm{ns}$ \\
\hline Wkładka domaciczna & $7(2,2 \%), 0,6-3,9$ & $6(1,9 \%)$ & $1(0,3 \%)$ & $\mathrm{ns}$ \\
\hline Stosunek przerywany & $6(1,9 \%), 0,4-3,5$ & $0(0 \%)$ & $6(1,9 \%)$ & $\mathbf{0 , 0 0 7 1}$ \\
\hline Plaster antykoncepcyjny & $3(0,9 \%),-0,1-2,1$ & $0(0 \%)$ & $3(0,9 \%)$ & $\mathrm{ns}$ \\
\hline Krążek antykoncepcyjny & $2(0,6 \%),-0,3-1,5$ & $0(0 \%)$ & $2(0,6 \%)$ & $\mathrm{ns}$ \\
\hline
\end{tabular}

ns - not significant, nieistotne statystycznie

Medical University students were statistically significantly more likely to have ever been tested for STIs: $22 \%$ vs $8.45 \%(p=0.0011)$ and have more knowledge of the places where such examinations were performed: $71.4 \%$ vs $26.8 \%$ ( $p<0.0001)$. In case of suspicion of STIs, students would report to doctors of the following specialties: gynecologist - 53.2\% (165, 95\% CI: 48 - 59) (24.8\% med., $28.4 \%$ non-med.), venereology dermatologist - 24.2\% (75, 95\% CI: 19 - 29) (18.4\% med., 5.8\% non-med.), family medicine physician - 14.8\% (46, 95\% CI: 11 - 19) $(8.1 \%$ med., $6.8 \%$ non-med.), infectious diseases physician $-4.8 \%$ (15, 95\% CI: 2 - 7) (1.6\% med., 3.2\% non-med.). Only one of the respondents from the Medical University admitted that they had not heard about STIs. When asked about known sexually transmitted infections, the respondents indicated: HIV/AIDS 97.7\% (303,
Medycznego istotnie statystycznie częściej byli kiedykolwiek badani w kierunku STIs: $22 \%$ vs $8,45 \%$ ( $\mathrm{p}=$ $0,0011)$ oraz mają większą wiedzę o miejscach wykonywania takich badań: $71,4 \%$ vs $26,8 \%$ ( $<<0,0001)$. $\mathrm{W}$ razie podejrzenia $\mathrm{u}$ siebie STIs studenci zgłosiliby się do lekarzy następujących specjalności: ginekolog $53,2 \%$ (165, 95\% CI: 48 - 59) $(24,8 \%$ med., $28,4 \%$ niemed.), dermatolog wenerolog - 24,2\% (75, 95\% CI: 19 - 29) (18,4\% med., 5,8\% niemed.), lekarz medycyny rodzinnej - 14,8\% (46, 95\% CI: 11 - 19) (8,1\% med., 6,8\% niemed.), lekarz chorób zakaźnych - 4,8\% (15, 95\% CI: $2-7)$ (1,6\% med., 3,2\% niemed.). Spośród wszystkich badanych tylko jedna osoba z Uniwersytetu Medycznego przyznała, że nie słyszała na temat STIs. W pytaniu o wybór infekcji należących do przenoszonych drogą płciową respondenci zaznaczali: HIV/AIDS 97,7\% (303, 95\% CI: 96 - 99), rzeżączka 92,9\% (288, 95\% CI: 90 - 
95\% CI: 96 - 99), gonorrhea 92.9\% (288, 95\% CI: 90 - 96), trichomoniasis 75.5\% (234, 95\% CI: 71 80), syphilis $89.3 \%$ (277, 95\% CI: 86 - 93), genital herpes $92.2 \%$ (286, 95\% CI: 89 - 95 ), HPV 70\% (217, 95\% CI: 64 - 75), chlamydiosis 69\% (214, 95\% CI: 64 - 74), hepatitis B 51\% (158, 95\% CI: 45 - 57) (Tab. IV.). It was shown that students of medical faculties classified these infections as STIs significantly better
96), rzęsistkowica 75,5\% (234, 95\% CI: 71 - 80), kiła 89,3\% (277, 95\% CI: 86 - 93), opryszczka narządów płciowych 92,2\% (286, 95\% CI: 89 - 95), HPV 70\% (217, 95\% CI: 64 - 75), chlamydioza 69\% (214, 95\% CI: 64 - 74), WZW B 51\% (158, 95\% CI: 45 - 57). (Tab. IV.) Wykazano, że studenci kierunków medycznych znamiennie poprawniej klasyfikowali wymienione infekcje do STIs w porównaniu do studentów kierunków nie-

Table IV. Which infections belong to STIs? Answers of the medical and non-medical students. Tabela IV. Które z infekcji należą do STIs? Odpowiedzi studentów medycznych i niemedycznych.

\begin{tabular}{|l|c|c|c|c|}
\hline \multirow{2}{*}{ Które z infekcji należą do STIs? } & \multirow{2}{*}{ Ogółem, 95\% CI } & \multicolumn{2}{c|}{ Studenci } \\
\cline { 3 - 5 } & & Medyczni & Niemedyczni & \\
\hline HIV & $303(97,7 \%), 96-99$ & $167(53,9 \%)$ & $136(43,9 \%)$ & $\mathbf{0 , 0 3 2 1}$ \\
\hline Rzeżączka & $288(92,9 \%), 90-96$ & $165(53,2 \%)$ & $123(39,7 \%)$ & $<\mathbf{0 , 0 0 0 1}$ \\
\hline rzęsistkowica & $234(75,5 \%), 71-80$ & $165(53,2 \%)$ & $69(22,2 \%)$ & $<\mathbf{0 , 0 0 0 1}$ \\
\hline Kiła & $277(89,3 \%), 86-93$ & $163(52,6 \%)$ & $114(36,8 \%)$ & $<\mathbf{0 , 0 0 0 1}$ \\
\hline Opryszczka narządów płciowych & $286(92,2 \%), 89-95$ & $164(52,9 \%)$ & $122(39,4 \%)$ & $\mathbf{0 , 0 0 0 1}$ \\
\hline HPV & $217(70 \%), 64-75$ & $148(47,7 \%)$ & $69(22,2 \%)$ & $<\mathbf{0 , 0 0 0 1}$ \\
\hline Chlamydioza & $214(69 \%), 64-74$ & $143(46,1 \%)$ & $71(22,9 \%)$ & $<\mathbf{0 , 0 0 0 1}$ \\
\hline WZW B & $158(51 \%), 45-57$ & $121(39 \%)$ & $37(11,9 \%)$ & $<\mathbf{0 , 0 0 0 1}$ \\
\hline
\end{tabular}

ns - not significant, nieistotne statystycznie

compared to students of non-medical faculties ( $\mathrm{p}$ $<0.0001)$. Almost $85 \%$ of respondents (95\% CI: $81-$ 89) $(51.9 \%$ of med. and $31.9 \%$ of non-med.) indicated that a virus is the etiological factor of HIV infection. Respondents from medical faculties showed a significant difference in knowledge of the causative microorganism compared to non-medical subjects ( $\mathrm{p}<0.0001)$. The most commonly picked ways of transmitting STIs were sexual contact - 97.4\% (302, 95\% CI: 96 - 99), sharing needles - 68.1\% (211, 95\% CI: 63 - 73), transplacental route - 64.8\% (201, 95\% CI: 59 - 70), oral contact - 55.2\% (171, 95\% CI: 50 61), blood transfusion - 54.5\% (169, 95\% CI: 63 - 73), sharing towels 33.2\% (103, 95\% CI: 28 - 39) (Tab. V.) A difference in knowledge about the transmission of STIs was found between the surveyed groups medycznych $(\mathrm{p}<0,0001)$. Blisko 85\% (95\% CI: 81 - 89) (51,9\%\% med. i 31,9\% niemed.) respondentów podało, że czynnikiem etiologicznym infekcji HIV jest wirus. Ankietowani z kierunków medycznych wykazali znamienną różnicę znajomości drobnoustroju wywołującego w porównaniu do osób z kierunków niemedycznych $(\mathrm{p}<0,0001)$. Jako potencjalne drogi przenoszenia STIs respondenci najczęściej podali kontakt płciowy - 97,4\% (302, 95\% CI: 96 - 99), używanie wspólnych igieł - 68,1\% (211, 95\% CI: 63 - 73), drogę przezłożyskową - 64,8\% (201, 95\% CI: 59 - 70), kontakt oralny - 55,2\% (171, 95\% CI: 50 - 61), transfuzję krwi - 54,5\% (169, 95\% CI: 63 - 73), korzystanie ze wspólnych ręczników 33,2\% (103, 95\% CI: 28 - 39) (Tab. V.) Między ankietowanymi grupami studentów wykazano różnicę w wiedzy na temat transmisji STIs, istotnie statystycz-

Table V. Ways of transmission of STIs chosen by medical and non-medical students.

Tabela V. Drogi przenoszenia STIs wybrane przez studentów medycznych i niemedycznych.

\begin{tabular}{|l|c|c|c|c|}
\hline \multirow{2}{*}{ Drogi przenoszenia STIs } & \multirow{2}{*}{ Ogółem, 95\% CI } & \multicolumn{2}{c|}{ Studenci } & \multirow{2}{*}{$\mathrm{p}$} \\
\cline { 3 - 5 } & & medyczni & niemedyczni & \\
\hline Kontakt płciowy & $302(97,4 \%), 96-99$ & $165(53,2 \%)$ & $137(44,2 \%)$ & $\mathrm{ns}$ \\
\hline Używanie wspólnych igieł & $211(68,1 \%), 63-73$ & $113(36,5 \%)$ & $98(31,6 \%)$ & $\mathrm{ns}$ \\
\hline Droga przezłożyskowa & $201(64,8 \%), 59-7-$ & $134(43,2 \%)$ & $67(21,6 \%)$ & $<\mathbf{0 , 0 0 0 1}$ \\
\hline Kontakt oralny & $171(55,2 \%), 50-61$ & $121(39 \%)$ & $50(16,1 \%)$ & $<\mathbf{0 , 0 0 0 1}$ \\
\hline Transfuzja krwi & $169(54,5 \%), 63-73$ & $100(32,3 \%)$ & $69(22,2 \%)$ & $\mathrm{ns}$ \\
\hline Korzystanie ze wspólnych ręczników & $103(33,2 \%), 28-39$ & $75(24,2 \%)$ & $28(9 \%)$ & $<\mathbf{0 , 0 0 0 1}$ \\
\hline
\end{tabular}

ns - not significant, nieistotne statystycznie 
of students: statistically significantly more often medical students marked the transplacental route ( $p$ $<0.0001)$, oral contact $(\mathrm{p}<0.0001)$, sharing of towels $(\mathrm{p}<0.0001)$. Almost $3 / 4(230,95 \%$ CI: $69-79)(50.3 \%$ med., $23.9 \%$ non-med.) of students know that sexually transmitted diseases can be asymptomatic, but it has been shown that medical subjects significantly more often chose this answer $(p<0.0001)$. The most known symptoms of STIs were classified by the respondents as: abnormal vaginal or urethral outlet discharge $76.1 \%$ (236, 95\% CI: 71 - 81), genital ulceration $77.1 \%$ (239, 95\% CI: $72-82$ ), genital pruritus $79 \%(245$, 95\% CI: 74 - 84), genital edema $73.9 \%(229,95 \%$ CI: 69 - 79), pain during intercourse $71.3 \%$ (221, 95\% CI: 66-76), pain while urinating $75.2 \%(233,95 \% \mathrm{CI}$ : $70-80)$. (Tab. VI.) Nearly $14 \%$ of the respondents did not indicate any symptoms. There was a difference in the knowledge of symptoms that may indicate STIs between the two groups of students with the indication of people from medical faculties $(\mathrm{p}<0.0001)$. Most of nie częściej studenci medyczni zaznaczali drogę przezłożyskową ( $<<0,0001)$, kontakt oralny $(p<0,0001)$, korzystanie ze wspólnych ręczników $(\mathrm{p}<0,0001)$. Blisko 3/4 (230, 95\% CI: 69 - 79) (50,3\% med., 23,9\% niemed.) studentów wie, że choroby przenoszone drogą płciową mogą przebiegać bezobjawowo, jednak wykazano, że osoby z kierunków medycznych znamiennie częściej wybierały tę odpowiedź $(p<0,0001)$. Do najbardziej znanych objawów STIs respondenci zakwalifikowali: wyciek nieprawidłowej wydzieliny z pochwy lub ujścia cewki moczowej 76,1\% (236, 95\% CI: 71 - 81), owrzodzenie narządów płciowych 77,1\% (239, 95\% CI: 72 82), świąd narządów płciowych $79 \%$ (245, 95\% CI: 74 - 84), obrzęk narządów płciowych 73,9\% (229, 95\% CI: 69 - 79), ból podczas współżycia 71,3\% (221, 95\% CI: 66 - 76), ból przy oddawaniu moczu 75,2\% (233, 95\% CI: 70 - 80). (Tab. VI.) Blisko 14\% ankietowanych nie wskazało żadnych objawów. Wykazano różnicę w znajomości objawów mogących świadczyć o STIs między obiema grupami studentów ze wskazaniem osób z kie-

Table VI. Answers concerning symptoms of STIs among medical and non-medical students.

Tabela VI. Odpowiedzi dotyczące objawów STIs wśród studentów medycznych i niemedycznych.

\begin{tabular}{|c|c|c|c|c|}
\hline & \multirow{2}{*}{ Ogółem, 95\% CI } & \multicolumn{2}{|c|}{ Studenci } & \multirow{2}{*}{$\mathrm{p}$} \\
\hline & & medyczni & niemedyczni & \\
\hline $\begin{array}{c}\text { Czy STIs mogą przebiegać bezobjawowo? } \\
\text { Tak / Nie / Nie wiem }\end{array}$ & $230(74,2 \%), 69-79$ & $\begin{array}{c}156(50,3 \%) / \\
2(0,6 \%) / 10 \\
(3,2 \%)\end{array}$ & $\begin{array}{c}74(23,9 \%) / \\
6(1,9 \%) / 62 \\
(20 \%)\end{array}$ & $<\mathbf{0 , 0 0 0 1}$ \\
\hline \multicolumn{5}{|l|}{ Które objawy należą do STIs? } \\
\hline $\begin{array}{l}\text { Wyciek nieprawidłowej wydzieliny z pochwy } \\
\text { lub ujścia cewki moczowej }\end{array}$ & $236(76,1 \%), 71-81$ & $155(50 \%)$ & $81(26,1 \%)$ & $<0,0001$ \\
\hline Owrzodzenie narządów płciowych & $239(77,1 \%), 72-82$ & $153(49,4 \%)$ & $86(27,7 \%)$ & $<0,0001$ \\
\hline Świąd narządów płciowych & $245(79 \%), 74-84$ & $150(48,4 \%)$ & $95(30,6 \%)$ & $<0,0001$ \\
\hline Obrzęk narządów płciowych & $229(73,9 \%), 69-79$ & $139(44,8 \%)$ & $90(29 \%)$ & 0,0001 \\
\hline Ból podczas współżycia & $221(71,3 \%), 66-76$ & $135(43,5 \%)$ & $86(27,7 \%)$ & 0,0001 \\
\hline Ból przy oddawaniu moczu & $233(75,2 \%), 70-80$ & $134(43,2 \%)$ & $99(31,9 \%)$ & 0,0414 \\
\hline
\end{tabular}

ns - not significant, nieistotne statystycznie

the respondents $(93.9 \%, 95 \%$ CI: 91 - 97) indicated the need to treat sexual partners in case of symptoms of sexually transmitted infection. Only more than half of the respondents (95\% CI: 51-62) (44.2\% med., $12.3 \%$ non-med.) knew about the existence of vaccines against some STIs; it was significantly greater among medical students than non-med. $(\mathrm{p}<0.0001)$. The need to deepen the knowledge about STIs was indicated by the majority of respondents $-88.3 \%(274,95 \%$ CI: 85 - 92), including 51\% (158) med. vs. 37.4\% (116) nonmed. and it was significantly higher among students of medical faculties $(p=0.0017)$. Among the listed sources of knowledge about STIs, students indicated: Internet $89 \%$ (276, 95\% CI: 86 - 93), university $60.6 \%$ (188, 95\% CI: 55 - 66), books 46.8\% (145, $95 \%$ CI: runków medycznych $(\mathrm{p}<0,0001)$. Większość ankietowanych (93,9\%, 95\% CI: 91 - 97) wskazała konieczność leczenia partnerów seksualnych w przypadku wystąpienia objawów infekcji przenoszonej drogą płciową. Tylko ponad połowa respondentów (95\% CI: 51 - 62) (44,2\% med., $12,3 \%$ niemed.) posiadała wiedzę o istnieniu szczepionek przeciwko niektórym STIs, była ona znamiennie większa wśród studentów med. niż niemed. $(p<0,0001)$. Potrzeba pogłębienia wiedzy na temat STIs została wskazana przez większą część ankietowanych - 88,3\% (274, 95\% CI: 85 - 92), w tym 51\% (158) med. vs. $37,4 \%$ (116) niemed. i była ona znamiennie większa wśród studentów kierunków medycznych $(\mathrm{p}=0,0017)$. Wśród wymienionych źródeł wiedzy o STIs studenci wskazali: Internet 89\% (276, 95\% CI: 86 - 93), uczelnia 
41 - 52), friends $15.8 \%$ (49.95\% CI: 12 - 20), family $5.5 \%(17.95 \%$ CI: 3 - 8). There were no statistically significant differences in the answers to this question between the study groups. Almost $90 \%$ of students did not know any preventive actions (posters, leaflets, information on the Internet) regarding STIs; such knowledge was reported by only $7.7 \%$ of medical and $3.5 \%$ non-medical students.

\section{DISCUSSION}

In recent years, the incidence and negative consequences of sexually transmitted diseases have increased significantly. Every day, over a million people around the world become infected. It is estimated that about 376 million infections occur annually, out of the four most common: chlamydia, gonorrhea, syphilis and trichomoniasis (1). Their consequence is acute infections, often exclusion from social functions, infertility, as well as organ and psychological complications (4). The above information proves the seriousness of the problem, which prompted us to test the knowledge and awareness of students.

In our study, the majority of respondents were women, which undoubtedly affects the obtained results and does not correspond to the structure of the student body in the city. On the other hand, it indicates that women are more interested than men in the subject matter and there is a need to provide knowledge and education, especially to men. Samkange-Zeeb et al. found that women were better informed about some STIs, such as HPV infection and chlamydiosis (5). The CDC (Centers for Disease Control and Prevention) reports that sexually active young adults (20-24 years) and adolescents (15-19 years) are at greater risk of STIs compared to older adults (6). According to Smith et al., the incidence of STIs is observed mainly among young people under 25 years of age, which is most likely caused by exposure to the main risk factors: intercourse with multiple partners and not using condoms (7). Our respondents were on average 22 years old, sexually active people. Recently, the age of sexual initiation has been lowered, which means that younger and younger people are exposed to the microorganisms causing STIs (8). Almost half of the respondents declared the occurrence of risky sexual behaviour, which is quite a large number of students, comparing our study to others of this type (5). However, Wayal et al. in their UK study showed that $59.2 \%$ of respondents admitted to such behaviour. Such a large percentage may result from the fact that the respondents in the Wayal et al. study were MSM (9). There are many studies confirming the correlation between the risk factors
60,6\% (188, 95\% CI: 55 - 66), książki 46,8\% (145, 95\% CI: 41 - 52), znajomi 15,8\% (49, 95\% CI: 12 - 20), rodzina 5,5\% (17, 95\% CI: 3 - 8). Nie stwierdzono różnic w odpowiedzi na to pytanie pomiędzy badanymi grupami. Blisko 90\% studentów nie znało żadnych akcji profilaktycznych (plakaty, ulotki, informacje w internecie) dotyczących STIs, taką znajomość podało jedynie $7,7 \%$ studentów kierunków medycznych i 3,5\% niemedycznych.

\section{OMÓWIENIE}

W ostatnich latach znacząco wzrasta zachorowalność i negatywne konsekwencje chorób przenoszonych drogą płciową. Każdego dnia na całym świecie zakażeniu ulega ponad milion osób. Szacuje się, że co roku pojawia się około 376 milionów infekcji z czterech najczęściej występujących: chlamydiozy, rzeżączki, kiły oraz rzęsistkowicy (1). Ich konsekwencją są ostre infekcje, często wykluczenie z funkcji społecznych, bezpłodność oraz powikłania narządowe i psychologiczne (4). Powyższe informacje świadczą o powadze problemu, co skłoniło nas do sprawdzenia wiedzy i świadomości studentów.

W naszym badaniu większość respondentów stanowiły kobiety, co niewątpliwie ma wpływ na uzyskane wyniki i nie odpowiada strukturze ogółu studentów w mieście. Z drugiej jednak strony, wskazuje to na większe zainteresowanie kobiet niż mężczyzn poruszoną tematyką oraz potrzebę pogłębiania wiedzy i edukacji, zwłaszcza wśród płci męskiej. Samkange-Zeeb i wsp. stwierdzili lepsze poinformowanie kobiet na temat niektórych z STIs, jak infekcja HPV i chlamydioza (5). CDC (Centers for Disesase Control and Prevention) podaje, że młodzi dorośli (20-24 lata) i osoby nastoletnie (15-19 lat) aktywne seksualnie są bardziej zagrożone STIs w porównaniu do starszych dorosłych (6). Według Smith i wsp. zachorowalność na STIs obserwowana jest głównie wśród ludzi młodych poniżej 25. roku życia, co najprawdopodobniej spowodowane jest narażeniem na główne czynniki ryzyka: współżycie z wieloma partnerami oraz niestosowanie prezerwatyw (7). Badani przez nas respondenci mieli średnio 22 lata, osoby aktywne seksualnie były w podobnym wieku - średnio 22,3 roku. W ostatnim czasie dochodzi do obniżenia wieku inicjacji seksualnej, co powoduje, że coraz młodsi są eksponowani na drobnoustroje powodujące STIs (8). Prawie połowa ankietowanych deklarowała wystąpienie ryzykownego zachowania seksualnego, co stanowi dość dużą liczbę studentów, porównując nasze badanie do innych tego typu (5). Jednakże Wayal i wsp. w swoim badaniu przeprowadzonym w Wielkiej Brytanii wykazał, że 59,2\% ankietowanych przyznało sią do takich zachowań. Tak duży odsetek, może wynikać z faktu, że respondentami byli MSM (9). Istnieje wiele badań po- 
for STIs (such as a large number of sexual partners, casual sexual intercourse, unprotected intercourse) and factors increasing the risk of these behaviours, such as alcohol and drug use $(10,11,12)$. A study by Richter et al. showed a correlation between the lack of condom use and a large number of sexual partners and aggressive behaviour (12). Interestingly, according to a study by Senf et al., alcohol use is not the largest risk factor for intercourse without using a condom (13). A survey conducted among students of universities in Tehran showed that as many as $85 \%$ of sexually active people had more than one partner in their lives, which, compared to our results, is a significantly higher value (14). In research conducted around the world, testing for STIs is more common than among students from Bialystok, where the percentage is $15.8 \%$. Wayal et al. report that $3 / 4$ of the respondents have ever been tested for these infections. Failure to perform such a test was associated with less knowledge about STIs and negative or unknown HIV status (9). In contrast, more than half of Scottish university students reported having tested for STIs in the past. According to Martin-Smith et al., it correlated with the female gender, older age, knowledge about STIs, own norms, attitudes and inclinations (7). In our study, the vast majority of respondents have never been tested for STIs, indicating the need for education, which may additionally be the reason for the low return rates in our study. Hamilton et al. found that low selfconfidence, access to test sites, stigmatization, discrimination, poverty, low awareness of the risk of HIV infection are the main obstacles to HIV testing (15). As in the studies by Zhang et al., the main source of knowledge about STIs for most students is the Internet, and in the event of being at risk of an STI infection, the majority of respondents (50.6\%) would seek medical advice (16). A study of MSM in China also reports that half of those polled would see a doctor. Factors influencing failure to report to professionals are younger age, lower income, less knowledge of STIs, and no symptoms (17). In the study by Kaptanoğlu et al., the main source of information is often school, and medical authorities are not mentioned in the first place (18). Respondents' lack of knowledge may be related to the lack of reliable sources of information - there are many websites providing professional knowledge in this field, but unfortunately the Internet is also abundant in scientifically unsubstantiated, amateur opinions and advice. Very often, the selection of reliable sources worth attention is difficult for students, especially in the case of students of non-medical faculties. On the other hand, respondents from medical faculties often have theoretical knowledge gained from studies, such twierdzających korelację pomiędzy czynnikami ryzyka STIs (jak duża liczba partnerów seksualnych, przygodne stosunki seksualne, stosunek bez zabezpieczenia) oraz czynnikami zwiększającymi ryzyko wystąpienia tych zachowań, jak alkohol, narkotyki $(10,11,12)$. W badaniu przeprowadzonym przez Richter i wsp. wykazano korelację między brakiem stosowania prezerwatyw a dużą liczbą partnerów seksualnych i agresywnym zachowaniem (12). Co ciekawe, wg badania przeprowadzonego przez Senf i wsp. używanie alkoholu nie jest największym z czynników ryzyka stosunku bez zastosowania prezerwatywy (13). Ankieta przeprowadzona wśród studentów uczelni wyższych w Teheranie wykazała, że aż $85 \%$ osób aktywnych seksualnie w swoim życiu miało więcej niż jednego partnera, co w porównaniu do naszych wyników jest znacząco wyższą wartością (14). W badaniach przeprowadzonych na świecie testowanie w kierunku STIs jest bardziej powszechne niż wśród studentów z Białegostoku, gdzie odsetek ten wynosi $15,8 \%$. Wayal i wsp. podają, że $3 / 4$ respondentów miało kiedykolwiek wykonane badanie w kierunku tych zakażeń. Niewykonywanie takiego badania było związane z mniejszą wiedzą na temat STIs oraz negatywnym lub nieznanym statusem HIV (9). Z kolei ponad połowa studentów szkockich uniwersytetów deklarowała wykonanie badania w kierunku STIs w przeszłości. Według Martin-Smith $i$ wsp. korelowało to z płcią żeńską, starszym wiekiem, wiedzą na temat STIs, własnymi normami, postawami i skłonnościami (7). W naszym badaniu znacząca większość respondentów nigdy nie była badana w kierunku STIs, co wskazuje na potrzebę edukacji, co dodatkowo może być powodem niskich odsetek zwrotu w naszym badaniu. Hamilton i wsp. określili, że niska pewność siebie, dostęp do miejsc wykonywania badań, stygmatyzacja, dyskryminacja, bieda, niska świadomość ryzyka infekcji HIV są głównymi przeszkodami w przeprowadzaniu testów na obecność wirusa HIV (15). Podobnie jak w badaniach Zhang i wsp., głównym źródłem wiedzy na temat STIs u większości studentów jest Internet, a w przypadku narażenia na ryzyko zakażenia STIs większość badanych $(50,6 \%)$ udałaby się po poradę lekarską (16). Badanie wśród MSM w Chinach również podaje, że połowa badanych zgłosiłaby się do lekarza. Czynnikami mającymi wpływ na niezgłaszanie się do profesjonalistów są młodszy wiek, mniejszy dochód, mniejsza wiedza na temat STI czy brak objawów (17). W badaniu Kaptanoğlu i wsp. głównym źródłem informacji często pozostaje szkoła, a autorytety medyczne nie są wymieniane w pierwszej kolejności (18). Niedoinformowanie respondentów może wiązać się z brakiem rzetelnych źródeł informacji - istnieje wiele stron internetowych, dostarczających profesjonalnej wiedzy w tym zakresie, jednak niestety Internet obfituje również w niepotwierdzone naukowo, amatorskie opinie i porady. Bardzo 
as knowledge of pathogens or names of diseases, but probably quite often they are not able to use this knowledge in practice. While our study surveyed only a randomly selected group of students of Bialystok universities, it is not a local problem - authors of studies around the world come to similar conclusions (16). According to Mudassir et al., newspapers and magazines are the main source of patient knowledge in Malaysia, while hospitals and health care facilities are the last. Shapiro et al. addressed a similar issue - the discrepancy between knowledge, care and behavior (20). Young people should not be accused of a complete lack of knowledge, but it is important to pay attention to their approach and attitude towards STIs. Our study reported that $7.7 \%$ of students would wait for symptoms of the disease, which is caused by their unawareness of the asymptomatic course of some STIs that can potentially cause an accidental transmission to their sexual partners and further spread of the disease. Considering the methods of contraception, the vast majority of students indicated the use of a condom, which is the most widespread and available protection all over the world (21).

The majority of students participating in the survey (99.4\% med., 95.8\% non-med.) pointed out the HIV as a sexually transmitted pathogen, which may partially prove the positive impact of sexual education concerning the virus. However, according to WHO, in 2018, HIV infection was noted in about 38 million cases worldwide. This may indicate low level of education and awareness of STIs (22).

The most common cause of anal-genital ulcers is the herpes virus HSV-2. Its characteristic symptoms were recognized by our respondents as the second most common symptom of STIs. (23). HPV infection is the most common STI in the world. With the introduction of HPV vaccinations in some countries, a strong decrease in the occurrence of STI infection and cervical cancer was noticed (24). The results of our survey showed that over a quarter of non-medical students were not aware of the possibility of getting vaccinated against HPV, while over $80 \%$ of medical students had such knowledge. This outcome shows the differences in knowledge between both groups, but also the need for greater education, especially among young people.

According to the European guidelines for the diagnosis and treatment of sexually transmitted infections, it is very important that infected patients encourage their sexual partners to visit the appropriate centers for check-up and possible treatment (25). Most of our respondents pointed out the need to treat sexual partners in the case of occurrence of symptoms, which is a positive trend. It is essential to know how STIs spread (26). Our study często selekcja rzetelnych źródeł wartych uwagi sprawia studentom trudność, szczególnie w przypadku studentów kierunków niemedycznych. Ankietowani z kierunków medycznych za to często posiadają wiedzę teoretyczną wyniesioną ze studiów, jak znajomość patogenów, nazw chorób, jednak prawdopodobnie dość często nie potrafią wykorzystać tej wiedzy w praktyce. Nie jest to problem lokalny, jak wykazano na wybranej przez nas losowo grupie studentów białostockich uczelni, do podobnych wniosków dochodzą autorzy badań na całym świecie (16). Według Mudassir i wsp., głównym źródłem wiedzy pacjentów w Malezji są gazety i czasopisma, podczas gdy szpitale i placówki ochrony zdrowia są na ostatnim miejscu spośród podawanych źródeł informacji (19). Shapiro i wsp. poruszyli podobne zagadnienie - rozbieżność między wiedzą, troską a zachowaniem (20). Nie można zarzucić młodym ludziom zupełnego braku wiedzy, jednak należałoby zwrócić uwagę na ich podejście i stosunek do STIs. W naszym badaniu odnotowano, że 7,7\% studentów czekałoby na objawy choroby - ma to związek z nieświadomością studentów na temat bezobjawowego przebiegu niektórych z STIs. W takiej sytuacji mogą oni stwarzać potencjalne zagrożenie przypadkowego zakażania swoich partnerów seksualnych i rozprzestrzeniania chorób. Biorąc pod uwagę stosowane metody antykoncepcji, znacząca większość studentów wskazała prezerwatywę, która jest najbardziej rozpowszechnionym i dostępnym środkiem na całym świecie (21).

Zdecydowana większość studentów biorących udział w ankiecie (99,4\% med., 95,8\% niemed.) wskazała HIV jako patogen przenoszony drogą płciową, co częściowo może świadczyć o pozytywnym wpływie edukacji seksualnej dotyczącej tego wirusa. Jednak jak podają dane WHO z 2018 r. występowanie zakażenia wirusem HIV odnotowano u około $38 \mathrm{mln}$ ludzi na całym świecie, co wskazuje nadal na braki w edukacji i świadomości dotyczącej STIs (22).

Najczęstszą przyczyną występowania owrzodzeń okolicy analno-genitalnej jest wirus opryszczki HSV2. Tak charakterystyczne objawy były rozpoznawane przez naszych respondentów jako drugi najczęstszy objaw STIs. (23).

Zakażenie wirusem HPV jest najczęstszym STIs na świecie. Dzięki szczepieniom zauważono bardzo duży spadek występowania tych infekcji w obrębie narządów płciowych oraz spadek zachorowalności na raka szyjki macicy w krajach, które wprowadziły tą szczepionkę (24). Jak wynika z uzyskanych wyników, ponad 1/4 studentów kierunków niemedycznych nie była świadoma możliwości zaszczepienia się przeciwko wirusowi HPV, podczas gdy ponad $80 \%$ studentów kierunków medycznych posiadała taką wiedzę. Po raz kolejny wskazuje to na różnice w wiedzy pomiędzy badanymi grupami, 
showed that sexual intercourse is considered the most common way of transmitting infections, while oral intercourse is seen as much less common - it took the fourth place. That outcome highlights the need for education.

The results of the presented work revealed that a small percentage of students, regardless of their fields of studies, have knowledge about preventive or educational campaigns concerning sexual health. It is worth mentioning the existence of educational programs proposed by WHO, PTS (Polish Sexological Society) or PTMS (Polish Society of Sexual Medicine) (27). Sexual health education increases motivation to prevent STIs and therefore reduces morbidity (28).

The data presented in this paper not be treated as crucial, due to various methodological problems, e.g. related to gender imbalance. Although the study group is not fully representative of all students of Bialystok universities, it should be emphasized that the obtained data present the state of knowledge and preventive behavior of young people regarding STIs, and additionally encourage further, multi-center research on this subject.

\section{CONCLUSIONS}

In brief, this paper summarizes the state of knowledge, risky behaviors and preventive actions concerning STIs as presented by students from Bialystok universities. The results of our survey emphasize the great need for education among young people, especially students of non-medical universities. The education should be focused on pathogens other than HIV and possible symptoms accompanying the infection, as well as the possibility of asymptomatic course and also the need to inform and treat sexual partners. Another aspect of the problem is educating young people about the need to test for STIs, especially in the case of having sexual intercourse with multiple partners, unprotected intercourse or intercourse after using alcohol or drugs. Sexually transmitted infection has both health and psychosocial consequences. Due to the fact that the age of sexual initiation in Poland is decreasing, it is necessary to spread knowledge about STIs, including educational campaigns and preventive actions from an early age, in order to avoid the diseases and their complications.

\section{REFERENCES}

1. World Health Organization. Report on global sexually transmitted infection surveillance, 2018. Geneva: WHO, 2018; :1-3. ale również potrzebę większej edukacji społeczeństwa, zwłaszcza osób młodych.

Według wytycznych Europejskich dotyczących postępowania diagnostycznego i leczniczego w zakażeniach przenoszonych drogą płciową bardzo ważne jest, aby wszystkie osoby z STIs powiadomily swoich partnerów seksualnych, aby zgłosili się do odpowiednich ośrodków, w celu sprawdzenia czy nie są zakażone i podjęcia ewentualnego leczenie (25). Większość naszych ankietowanych wskazała konieczność leczenia partnerów seksualnych w przypadku wystąpienia objawów infekcji przenoszonej drogą płciową, co jest pozytywnym aspektem. Znajomość dróg szerzenia się STIs odgrywa zasadnicze znaczenie (26). Nasze badanie pokazało, że kontakt płciowy jest uważany za najczęstszą drogą transmisji zakażeń, natomiast stosunek oralny dużo rzadziej - dopiero na czwartym miejscu. Wskazuje to po raz kolejny na potrzebę edukacji.

Wyniki przedstawionej pracy pokazują, jak mały odsetek studentów, bez względu na studiowane kierunki, ma wiedzę o akcjach profilaktycznych czy edukacyjnych o tematyce zdrowia seksualnego. Warto wspomnieć o kilku istniejących programach edukacyjnych zaproponowanych przez WHO, PTS (Polskie Towarzystwo Seksuologiczne) czy PTMS (Polskie Towarzystwo Medycyny Seksualnej) (27). Edukacja na temat zdrowia seksualnego zwiększa motywację do postępowania profilaktycznego w zakresie STIs, tym samym zmniejszając zachorowalność (28).

Przedstawione w niniejszej pracy dane nie mogą być traktowane jako ostateczne $\mathrm{z}$ uwagi na różne problemy metodologiczne, m.in. związane z dysproporcją płci. Mimo że badana grupa nie jest w pełni reprezentatywna dla wszystkich studentów białostockich uczelni, należy podkreślić, że uzyskane dane przedstawiają stan wiedzy i zachowania prewencyjne młodych ludzi odnośnie STIs, a dodatkowo zachęcają do dalszych, wieloośrodkowych badań w tej tematyce.

\section{WNIOSKI}

Podsumowując, w niniejszej pracy przedstawiono stan wiedzy, ryzykowne zachowania i działania prewencyjne dotyczące STIs praktykowane przez studentów z białostockich uczelni. Wyniki naszej ankiety podkreślają ogromną potrzebę dokształcenia młodych ludzi w tym zakresie, zwłaszcza studentów uczelni niemedycznych. Podczas edukacji należy zwrócić uwagę na patogeny inne niż HIV, które mogą wywołać STIs oraz na objawy, które mogą sugerować infekcję, jak również na możliwość bezobjawowego przebiegu oraz konieczność informowania i leczenia partnerów seksualnych. Kolejnym aspektem jest pouczenie młodych osób o konieczności przeprowadzania badań w kierunku STIs, zwłaszcza w przypadku odbywania stosunków 
2. Woynarowska B. Zachowania seksualnemłodzieży 15-letniej. W: Mazur J, red. Zdrowie i zachowania zdrowotne młodzieży szkolnej $\mathrm{w}$ Polsce na tle wybranych uwarunkowań socjodemograficznych. Wyniki badań HBSC 2014. Warszawa: Instytut Matki i Dziecka; 2015:193-199.

3. Izdebski Z, Wąż K. Zdrowie seksualne i reprodukcyjne młodzieży. Zdrowie Publiczne i Zarządzanie 2014;12(1):45-55.

4. World Health Organization. Global Health Sector Strategy on Sexually Transmitted Infections, 2016-2021. Geneva: WHO; 2016:6-17.

5. Samkange-Zeeb F, Mikolajczyk RT, Zeeb H. Awareness and Knowledge of Sexually Transmitted Diseases Among Secondary School Students in Two German Cities. J Community Health 2013;38(2):293-300.

6. Centers for Disease Control and Prevention. Sexually Transmitted Disease Surveillance 2017. Atlanta: U.S. Department of Health and Human Services 2018:49-54

7. Martin-Smith HA, Okpo EA, Bull ER. Exploring psychosocial predictors of STI testing in University students. BMC Public Health 2018;18(1):664.

8. Jarząbek-Bielecka G, Pisarska-Krawczyk M, Mizgier M. Preventing sexually transmitted diseases (including HPV and HIV) in the context of premature sexual initiation, health promotion, and other related issues for gynaecological practice - a review. J Health Inequal 2016;2(2):200-204.

9. Wayal S, Reid D, Weatherburn P, et al.. Association between knowledge, risk behaviours, and testing for sexually transmitted infections among men who have sex with men: findings from a large online survey in the United Kingdom. HIV Med 2019;20(8):523-533.

10. Cavazos-Rehg PA, Krauss M, Spitznagel EL, et al.. Number of sexual partners and associations with initiation and intensity of substance use. AIDS Behaviour 2011;15:869-74.

11. Calatrava M, López-Del Burgo C, de Irala J. Sexual risk factors among European young people. Med Clin (Barc) 2012;138(12):534-40.

12. Richter DL, Valois RF, McKeown RE, et al.. Correlates of condom use and number of sexual partners among high school adolescents. J Sch Health 1993;63(2):91-6.

13. Senf JH, Price CQ. Young adults, alcohol and condom use: what is the connection? J Adolesc Health 1994;15(3):238-44.

14. Khalajabadi Farahani F, Akhondi MM, Shirzad $\mathrm{M}$, et al.. Hiv/sti risk-taking sexual behaviours and risk perception among male university students in Tehran: implications for hiv prevention among youth. J Biosoc Sci 2018;50(1):86-101.

15. HamiltonA,ShinS, TaggartT,etal..HIVtestingbarriers and intervention strategies among men, transgender seksualnych z wieloma partnerami oraz współżycia bez zabezpieczenia, po alkoholu czy narkotykach. Zakażenie przenoszone drogą płciową niesie ze sobą konsekwencje zdrowotne, jak i psychosocjalne. Ze względu na to, że wiek inicjacji seksualnej w Polsce obniża się, konieczne jest szerzenie wiedzy odnośnie STIs, m.in. poprzez kampanie edukacyjne, akcje profilaktyczne już od najmłodszych lat, celem uniknięcia zachorowania i ich powikłań.

women, female sex workers and incarcerated persons in the Caribbean: a systematic review. Sex Transm Infect 2019; pii: sextrans-2018-053932. doi: 10.1136/ sextrans-2018-053932.

16. Zhang D, Pan H, Cui B, et al.. Sexual behaviors and awareness of sexually transmitted infections among Chinese university students. J Infect Dev Ctries 2013;7(12):966-974.

17. Li J, Yue X, Wang Y, iet al.. First responses to the symptoms of sexually transmitted infections and treatment seeking behavior among men who have sex with men in 13 cities in China. Sex Transm Dis. 2019 doi: 10.1097/OLQ.0000000000001074.

18. Kaptanoğlu AF, Süer K, Diktaş H, et al.. Knowledge, attitudes and behaviour towards sexually transmitted diseases in Turkish Cypriot adolescents. Cent Eur J Public Health 2013;21(1):54-58.

19. Anwar M, Sulaiman SA, Khan TM. A survey of knowledge of sexually transmitted infections among patients at a public hospital in Pulau Pinang, Malaysia. Med Princ Pract 2010;19(4):312-8.

20. Shapiro J, Radecki S, Charchian A, et al.. Sexual behavior and AIDS-related knowledge among community college students in Orange County, California. Journal of Community Health 1999;24(1),229-243.

21. Folasayo AT, Oluwasegun AJ, Samsudin S, et al.. Assessing the Knowledge Level, Attitudes, Risky Behaviors and Preventive Practices on Sexually Transmitted Diseases among University Students as Future Healthcare Providers in the Central Zone of Malaysia: A Cross-Sectional Study. Int J Environ Res Public Health 2017;14(2):159.

22. Cybula A, Kwiatkowska M. Zakażenia przenoszone drogą płciową - wybrane zagadnienia. Dermatologia po dyplomie 2019;10(6).

23. Wagenlehner FM, Brockmeyer NH, Discher T, et al.. The Presentation, Diagnosis, and Treatment of Sexually Transmitted Infections. Dtsch Arztebl Int 2016;113(1-02):11-22.

24. Gottlieb SL, Johnston C. Future prospects for new vaccines against sexually transmitted infections. Curr Opin Infect Dis 2017;30(1):77-86.

25. Golden MR, Whittington WLH, Handsfield HH, et al.. Effect of expedited treatment of sex partners on 
recurrent or persistent gonorrhoea or chlamydial infection. New England Journal of Medicine 2005;352:676-685

26. Ludwikowska K, Karlikowska-Skwarnik M, Szenborn L. Choroby przenoszone drogą płciowa u nastolatków. Forum Położnictwa i Ginekologii 2017;04:20-32

27. Zbigniew Lew-Starowicz, Monika Łukasiewicz. Seksualne aspekty chorób przenoszonych drogą płciową. Post Nauk Med 2008;04:228-230

28. Jarząbek-Bielecka G, Pawlaczyk M, Pawlaczyk $\mathrm{M}$, i in. Problem stanów zapalnych żeńskich narządów płciowych - ocena wiedzy dziewcząt na temat profilaktyki i leczenia. Medycyna rodzinna 2018;1a;29-36.
Received: 16.12.2019 r.

Otrzymano: 16.12.2019 r.

Accepted for publication: $31.07 .2020 \mathrm{r}$.

Zaakceptowano do publikacji: 31.07.2020 r.

Address for correspondence:

Adres do korespondencji:

Paulina Grabowska, dr hab. Anna Baran

Klinika Dermatologii i Wenerologii

Uniwersytetu Medycznego w Białymstoku

ul. Żurawia 14

15-540 Białystok 